ROCZNIKI NAUK SPOŁECZNYCH

Tom 13(49), numer $2-2021$

DOI: https://doi.org/10.18290/rns21492.4

AGNIESZKA ZABOROWSKA

\title{
MODEL ROLI SPOŁECZNO-ZAWODOWEJ \\ PRACOWNIKA SOCJALNEGO \\ W KONTEKŚCIE TEORII RÓL. DYSKUSJA Z BADAŃ
}

\begin{abstract}
WPROWADZENIE
Profesja pracownika socjalnego wymaga budowania relacji z ludźmi i autentycznego kontaktu. Toteż obok elementów roli, wynikających z wymagań stricte zawodowych, nie do pominięcia są segmenty osobowościowe (Czechowska-Bieluga, 2013). Obecność, włączenie, autentyczne komunikowanie wydają się niezbędnym składnikiem roli społeczno-zawodowej pracownika socjalnego (Buber, 1992). Oczekiwania normatywne związane z bezpośrednią obsługą klientów pomocy społecznej są istotne nie tylko w kształtowaniu publicznego wizerunku pracownika socjalnego, lecz także wyznaczają subiektywne zadowolenie $\mathrm{z}$ aktywności zawodowej, poczucie spełnienia i skuteczności pracy. Zajmowane miejsce w społeczeństwie, stosunki i wymagania społeczne oraz predyspozycje i cechy indywidualne konstruują unikalną rolę społeczno-zawodową pracownika socjalnego (Kantowicz, Ciczkowska-Giedziun, Zmysłowska, 2018, s. 15-19). Analiza teorii ról społecznych oraz wyników badań własnych umożliwia zaproponowanie modelu roli społeczno-zawodowej pracownika socjalnego.
\end{abstract}

Dr AgniesZKa ZabOROWSKA - Katolicki Uniwersytet Lubelski Jana Pawła II, Wydział Nauk Społecznych, Instytut Nauk Socjologicznych, Katedra Socjologii Struktur, Procesów Społecznych i Pracy Socjalnej, Al. Racławickie 14, 20-950 Lublin; e-mail: agnieszka.zaborowska@kul.pl; ORCID: https://orcid.org/0000-0003-2568-2688. 


\section{TEORIA I STRUKTURA RÓL SPOŁECZNYCH}

Role społeczne, jakie pełni w trakcie życia każdy człowiek, są jednym z najbardziej zauważalnych i definiotwórczych elementów funkcjonowania ludzkiego. Poprzez pozycję społeczną i wynikającą z niej rolę ludzie definiują siebie nawzajem. W interakcjach i kontaktach społecznych orientujemy się na to, z kim mamy do czynienia i w jakiej sprawie możemy się do tego kogoś zwrócić. Identyfikacja roli społecznej każdorazowo wyprzedza działanie w kierunku nawiązania kontaktu. Rozpoznanie roli i pozycji społecznej z jednej strony niejako uprawnia nas do nawiązania interakcji, a z drugiej formułuje listę różnorodnych oczekiwań na temat partnera (Sztompka, 2003, s. 93). Oczekiwania wobec przedstawicieli ról społecznych formułowane są w postaci obowiązków i zadań, wynikających z zajmowanej w społeczeństwie pozycji. Taka koncepcja roli społecznej dominuje w naukach socjologicznych. Prezentuje ją m.in. teoria Talcotta Parsonsa ,pozycjo-roli” (status-role). Autor, wprowadzając owe pojęcie, chciał podkreślić nierozerwalność pozycji społecznej od roli i zaakcentować, iż jedna wynika z drugiej (Parsons, Smelser, 1975, s. 219-240). Na każdym, kto zajmuje określoną pozycję społeczną, spoczywają obowiązki i uprawnienia. Zakres tych oczekiwań i reguł właściwych dla danej pozycji jest nazywany rolą społeczną. Takie normatywne ujęcie roli oddziela ją niejako od osoby, a przypisuje wyłącznie do pozycji (Sztompka, 2003, s. 92-93). Podobne znaczenie nadają teorie funkcjonalistyczne, w których role społeczne są kulturowo ustalonymi i niezmiennymi faktami społecznymi. Zgodnie z tą koncepcją jednostki „uczą się” roli społecznej wynikającej z zajmowanej pozycji i odgrywają ją (Giddens, 2006, s. 51). Oznaczałoby to, że role społeczne nie są zależne ani związane $\mathrm{z}$ cechami osobowościowymi ludzi, nie podlegają kreatywności i negocjacjom wynikającym chociażby z warunków środowiskowych, a społeczne uczenie się ról jest wynikiem socjalizacji (Turnowiecki, 2001, s. 39). W literaturze przedmiotu znajduje się wiele definicji roli społecznej, które prezentują ją jako względnie stałą i sztywną predyspozycję osoby - czy to w systemie norm i reguł, czy w zachowaniu. Już klasyczne definicje roli zakładały stałość jej elementów. J. Szczepański np. definiował rolę społeczną jako „względnie stały i wewnętrznie spójny system zachowań będących reakcjami na zachowania innych osób, przebiegających według mniej lub więcej wyraźnie ustalonego wzoru" (Szczepański, 1970, s. 131). Innym przykładem może być definicja J.H. Turnera, który rolą społeczną nazywa ,zachowania poszczególnych jednostek w ramach pozycji społecznych $\mathrm{w}$ stosunku do siebie nawzajem oraz $\mathrm{z}$ uwzględnieniem norm 
i innych kulturowych symboli" (Turner, 1998, s. 232). W świetle tych analiz można stwierdzić, że pojęcie roli społecznej jest wyznaczone poprzez pewną strukturę - zbiór elementów. Wśród stałych elementów roli najczęściej są wymieniane: (1) spójny zespół przepisów i oczekiwań, (2) zbiór przywilejów, obowiązków i praw, (3) repertuar zachowań jednostek w konkretnych sytuacjach. Dodatkowo wszystkie elementy są wyznaczane przez pozycję społeczną, jaką zajmuje dana jednostka w społeczeństwie. Takie pojmowanie roli społecznej wydaje się pomijać ważny czynnik ludzki - mianowicie cechy osobowościowe i indywidualne predyspozycje do zajmowania jakiejś pozycji społecznej, a tym samym pełnienia określonej roli. Bo czy każdy człowiek może być lekarzem, policjantem, pilotem odrzutowca czy pracownikiem socjalnym? W rzeczywistości ludzie nie czekają biernie, aż ktoś im pozwoli zająć określoną pozycję społeczną czy też zaprogramuje na bycie kimś konkretnym. Proces socjalizacji daje jednostkom możliwość działania, które prowadzi do objęcia, a nie przyjęcia roli społecznej. Szczególnie ważne jest to $\mathrm{z}$ punktu widzenia sprawstwa danej osoby wykonującej jakiś zawód. Jak wykazują badania ${ }^{1}$, predyspozycje osobowościowe są często wyznacznikiem skuteczności roli społeczno-zawodowej.

\section{STRUKTURA ROLI SPOŁECZNO-ZAWODOWEJ PRACOWNIKÓW SOCJALNYCH. IMPLIKACJA BADAŃ}

\subsection{ZAGADNIENIA KONCEPCYJNE I METODOLOGIA BADAŃ}

Pojęcie roli społecznej jest trudne do jednoznacznego zdefiniowania, ponieważ można je odnieść do dwóch różnych obszarów społecznej rzeczywistości: normatywnej i behawioralnej. Zaprezentowane w poprzednim punkcie definicje roli społecznej pokazały tę dychotomię. O ile normatywna płaszczyzna jest bardziej uniwersalna, to zachowania odnoszą się już konkretnie do odtwórcy roli. Należy również zwrócić uwagę, iż osoba wypełniająca rolę społeczną działa w określonych warunkach - sprzyjających lub ograniczających wypełnianie oczekiwań. Koncepcja normatywna zakłada, że rola społeczna istnieje w świadomości społecznej niezależnie od ,aktora”, natomiast teoria behawioralna uwzględnia osobę wypełniającą rolę. W przypadku roli

\footnotetext{
${ }^{1}$ Badania własne autorki, opisane obszerniej w kolejnych punktach.
} 
wynikającej z aktywności zawodowej wydaje się to szczególnie ważne, gdyż wspomniane warunki są wyznaczone przez prawo, kulturę zawodu, strukturę organizacyjną instytucji itd. Oczekiwania społeczne wynikające z roli zawodowej mają szczególne znaczenie w przypadku zawodów pomocowych. Uwzględniając szczególne warunki pracy i podejmując próbę analizy roli społeczno-zawodowej, na uwagę zasługuje koncepcja Stanisława Nieciuńskiego, który jako elementy roli wymienia: przepis roli, role pełnione i role subiektywne (Nieciuński, 1979). Według tej koncepcji przepis roli można zdefiniować jako czynności mocno skorelowane z oczekiwaniami i oceną społeczną. Rola pełniona to faktyczne zachowania osoby będącej w danej roli. Rola subiektywna zawiera wyobrażenia ,aktora” o pełnionej roli. Koncepcja Nieciuńskiego posłużyła autorce do stworzenia modelu roli społeczno-zawodowej pracownika socjalnego opartej na trzech konstruktach: roli wyobrażonej, roli propagowanej i roli realizowanej. Zaproponowany model roli społeczno-zawodowej pracownika socjalnego można odnieść do struktury roli wynikającej z teorii i definicji roli społecznej.

Gdyby do definiowania roli społecznej posłużyć się metaforą „aktora na scenie teatralnej", to łatwo wykazać, że rola jest faktem zastanym, że istnieje wcześniej, zanim aktor ją zagra, że wyznacza aktorowi szczegółowe zachowania wynikające z oczekiwań innych (scenarzystów, reżysera, widzów itd.) i że w związku z tym aktor uczy się roli już określonej (Merton, 2002, s. 413). I o ile w przypadku roli teatralnej czy filmowej ma to sens i uzasadnienie, to w przypadku ról społeczno-zawodowych ta analogia nie może zostać zapożyczona dosłownie. Rola społeczna wynikająca z objęcia jakiegoś zawodu powinna uwzględniać istotny komponent osobowościowy, funkcjonalny (dotyczący funkcjonowania osoby w danym systemie, wyjaśniający funkcję zjawisk psychologicznych) (Levin, 1985).

Wspomniana teoria roli społeczno-zawodowej Nieciuńskiego uwzględnia funkcję osobowości poprzez włączenie elementu roli subiektywnej. Rola subiektywna zawiera bowiem psychiczną percepcję objętej roli w formie: wyobrażeń, wizji oraz indywidualnych sposobów zachowania w roli (Nieciuński, 1979). Element ten jest znaczący dla decyzji o objęciu roli, ponieważ poprzez wyobrażenia, jak dana rola będzie wyglądać, jednostka decyduje, czy chce i może objąć daną rolę. W badaniach autorki element roli subiektywnej analogicznie występuje jako konstrukt: rola wyobrażona. Definiując ten element, pracownicy socjalni ${ }^{2}$ mogli odnieść się do swoich wyobrażeń jeszcze sprzed podjęcia zatrudnienia.

\footnotetext{
${ }^{2}$ Respondenci w badaniach autorki.
} 
Prezentowane w niniejszym artykule zagadnienie stanowi wyodrębnioną część obszerniejszego projektu badawczego autorki, dotyczącego psychospołecznej pozycji pracowników pomocy społecznej. W ramach prowadzonych badań wyłonił się ciekawy wątek roli społeczno-zawodowej, dlatego też postanowiono zaprezentować go w osobnym artykule. W ramach zagadnień związanych z rolą społeczno-zawodową sformułowano następujące pytania badawcze:

- Jak pracownicy socjalni definiują swoją rolę społeczno-zawodową w trzech konstruktach: (1) rola wyobrażona, (2) rola propagowana, (3) rola realizowana?

- Jakie są predyspozycje i cechy osobowościowe, które zadecydowały o objęciu roli pracownika socjalnego?

- Co decyduje o skuteczności w realizacji roli pracownika socjalnego?

Badania zostały przeprowadzane metodą jakościowych badań terenowych, z użyciem techniki pogłębionych wywiadów indywidualnych. W badaniach jakościowych dotychczas wzięło udział 34 pracowników socjalnych z miast: Radom, Lublin, Puławy (badania, zapoczątkowane w listopadzie 2020 r., są kontynuowane; stanowią część szerszego projektu badawczego i zostaną zaprezentowane $w$ innym opracowaniu). Cały proces badawczy został zrealizowany zgodnie z zasadami metodologii badań socjologicznych i społecznych. Badania przygotowano na podstawie następującej literatury fachowej: Podstawy badań społecznych Earla Babbiego, Metodologia badań społecznych Stefana Nowaka, Badania ilościowe w naukach społecznych. Szkice metodologiczne Stanisława Juszczyka, Metody i techniki badań socjologicznych. Wybrane zagadnienia Luby Sołomy, Projektowanie badań naukowcyh. Metody jakościowe, ilościowe i mieszane Johna W. Creswella.

\subsection{WYNIKI BADAŃ WŁASNYCH}

Wypowiedzi pracowników socjalnych wskazują na prawidłowości w postrzeganiu siebie w roli społeczno-zawodowej. Tabela 1 przedstawia wypowiedzi badanych na temat pojmowania roli w trzech konstruktach. Pracownicy socjalni mogli wypowiadać się swobodnie, tworzyć definicje, używać metafor. Odpowiedzi w tabeli są umieszczone w następującej kolejności: od tych, które powtarzały się najczęściej, do najrzadziej wymienianych. 
Tabela 1. Percepcja roli społeczno-zawodowej pracowników socjalnych

\begin{tabular}{|c|c|c|}
\hline $\begin{array}{l}\text { Rola WYOBRAŻONA } \\
\text { (wyobrażenia nt. tego, kim } \\
\text { się będzie jako pracownik } \\
\text { socjalny: Jak sobie } \\
\text { wyobrażateś, kim będziesz, } \\
\text { co będziesz robić?) }\end{array}$ & $\begin{array}{l}\quad \text { Rola PROPAGOWANA } \\
\text { (zbiór oczekiwań społecznych, kulturo- } \\
\text { wych, zawodowych, ocen i reguł: } \\
\text { Czego oczekuja ode mnie inni?) }\end{array}$ & $\begin{array}{l}\text { Rola REALIZOWANA } \\
\text { (zbiór realnych zachowań } \\
\text { i uprawnień: Co faktycznie } \\
\text { robię, kim jestem?) }\end{array}$ \\
\hline $\begin{array}{l}\text { - będę zmieniać świat, } \\
\text { uzdrawiać świat i ludzi } \\
\text { - będę rozwiązywać } \\
\text { problemy wszystkich } \\
\text { - będę wpływać na } \\
\text { zmianę ludzkiego życia }\end{array}$ & $\begin{array}{l}\text { - bankomat } \\
\text { - Robin Hood } \\
\text { - prorok }\end{array}$ & $\begin{array}{l}\text { - urzędnik; } \\
\text { - robię wywiady; } \\
\text { - jestem od wszystkiego, } \\
\text { ale nic konkretnego; } \\
\text { - ankieter; } \\
\text { - pilnuję terminów } \\
\text { różnych decyzji }\end{array}$ \\
\hline $\begin{array}{l}\text { - wspierający rodzic } \\
\text { - surowy rodzic } \\
\text { - sprawiedliwy rodzic }\end{array}$ & $\begin{array}{l}\text { - że będę od wszystkiego } \\
\text { - że nie będę doradcą, tylko głównym } \\
\text { wykonawcą zmiany } \\
\text { - że ja rozwiążę wszystkie problemy } \\
\text { - opiekunka społeczna, która opiekuje } \\
\text { się, czyli wszystko robi za klienta } \\
\text { - że rozwiążę wszystkie problemy świata } \\
\text { - lek na całe zło, plaster (szybko i bez- } \\
\text { boleśnie) } \\
\text { - wyręczyciel }\end{array}$ & $\begin{array}{l}\text { - pomocna dłoń } \\
\text { - osoba wspierająca } \\
\text { - pomagam innym } \\
\text { - pomagam jak umiem }\end{array}$ \\
\hline $\begin{array}{l}\text { - osoba wspierająca } \\
\text { - będę rozwiązywać } \\
\text { trudne rodzinne sprawy }\end{array}$ & $\begin{array}{l}\text { - pracownik, który będzie jednocześnie } \\
\text { psychologiem, policjantem, } \\
\text { urzędnikiem i duchowym wsparciem } \\
\text { - terapeutą uzależnień, pedagogiem, } \\
\text { czasem lekarzem i jeszcze, że przewidzi } \\
\text { czyjeś niewłaściwe zachowanie }\end{array}$ & - buduję wizerunek \\
\hline - psycholog & $\begin{array}{l}\text { - od pracownika socjalnego często } \\
\text { oczekuje się, żeby nie zauważał } \\
\text { pewnych spraw i przymykał oko na } \\
\text { nieodpowiednie zachowania } \\
\text { - często oczekuje się jedynie uzyskania } \\
\text { środków finansowych bez chęci } \\
\text { rozwiązania problemu } \\
\text { - oczekuje się, że nie będzie męczył } \\
\text { i zadawał pytań i na pstryknięcie } \\
\text { palcem przyznawał świadczenia; } \\
\text { - ktoś, kto nie będzie przeszkadzał }\end{array}$ & $\begin{array}{l}\text { - osoba, która wyrabia } \\
\text { statystyki } \\
\text { - realizowanie } \\
\text { rozbudowanej biurokracji }\end{array}$ \\
\hline $\begin{array}{l}\text { - Superman } \\
\text { - będę robić dokładnie to, } \\
\text { czego ludzie potrzebują }\end{array}$ & $\begin{array}{l}\text { - osoba, na którą wylewa się całą } \\
\text { frustrację } \\
\text { - kozioł ofiarny }\end{array}$ & - dziecko we mgle \\
\hline
\end{tabular}

Źródto: opracowanie własne na podstawie badań własnych. 
Z wypowiedzi zebranych $w$ tabeli wyłania się silna konfrontacja roli wyobrażonej z dwiema pozostałymi. Stąd wniosek, że czynniki i predyspozycje osobowościowe mają duże znaczenie przy obejmowaniu roli społeczno-zawodowej i później przy jej realizacji. Różnice między rolą wyobrażoną a propagowaną i realizowaną dowodzą, że gdyby pracownicy socjalni mieli wiedzę na temat tego, że ich wizja roli znacznie różni się od rzeczywistości, to prawdopodobnie mało kto zdecydowałby się ją objąć. Potwierdzają to zresztą nastroje i emocje pracowników socjalnych, które można zaobserwować podczas wywiadów. Przy operacjonalizacji dokonano grupowania wypowiedzi respondentów i nadania nazw i znaczeń wyłaniających się funkcji i aktywności w poszczególnych konstruktach roli (Beckett, 2010, s. 133-190). Z roli wyobrażonej przebija się obraz wszechmocnego (wszechmogącego), sprawczego i sprawnego profesjonalisty, który zna sposoby i ma receptę na lepszy świat. Co ciekawe, pokrywa się to z wątkiem dotyczącym podjęcia decyzji o wyborze zawodu. Okazało się, że dominującymi cechami osobowości pracowników socjalnych są: odwaga, otwartość i zaangażowanie oraz przekonanie o własnej omnipotencji. Rola propagowana (wyrażająca oczekiwania społeczne) prezentuje się głównie jako: dostarczyciel dóbr, wykonawca zmiany, wyręczyciel, opiekun. Na podstawie wypowiedzi pracowników socjalnych rolę realizowaną (faktycznie wykonywane funkcje) można określić jako: rolę urzędniczą, ale i wspierającą. $Z$ określeniem tego konstruktu roli społeczno-zawodowej jest najwięcej kłopotu. Jest to swoisty paradoks, ponieważ wydawałoby się, że rolę faktycznie wykonywaną najłatwiej będzie określić, opisać przez jej wykonawców. Tymczasem w definiowaniu tej roli widać duże rozproszenie i niepewność. W sformułowaniach: „pomagam jak umiem”, ,jestem od wszystkiego”, „buduję wizerunek”, „dziecko we mgle”, jawi się spora wątpliwość co do funkcji, obowiązków, uprawnień i kompetencji. Interesujący jest jaskrawy brak wypowiedzi odnośnie do uprawnień pracowników socjalnych, co może świadczyć o ich niepokoju i niepewności co do swobody w realizacji roli zawodowej. Rysunek 1 obrazuje strukturę roli społeczno-zawodowej pracownika socjalnego z uwzględnieniem wykorzystanych w badaniach konstruktów roli. 


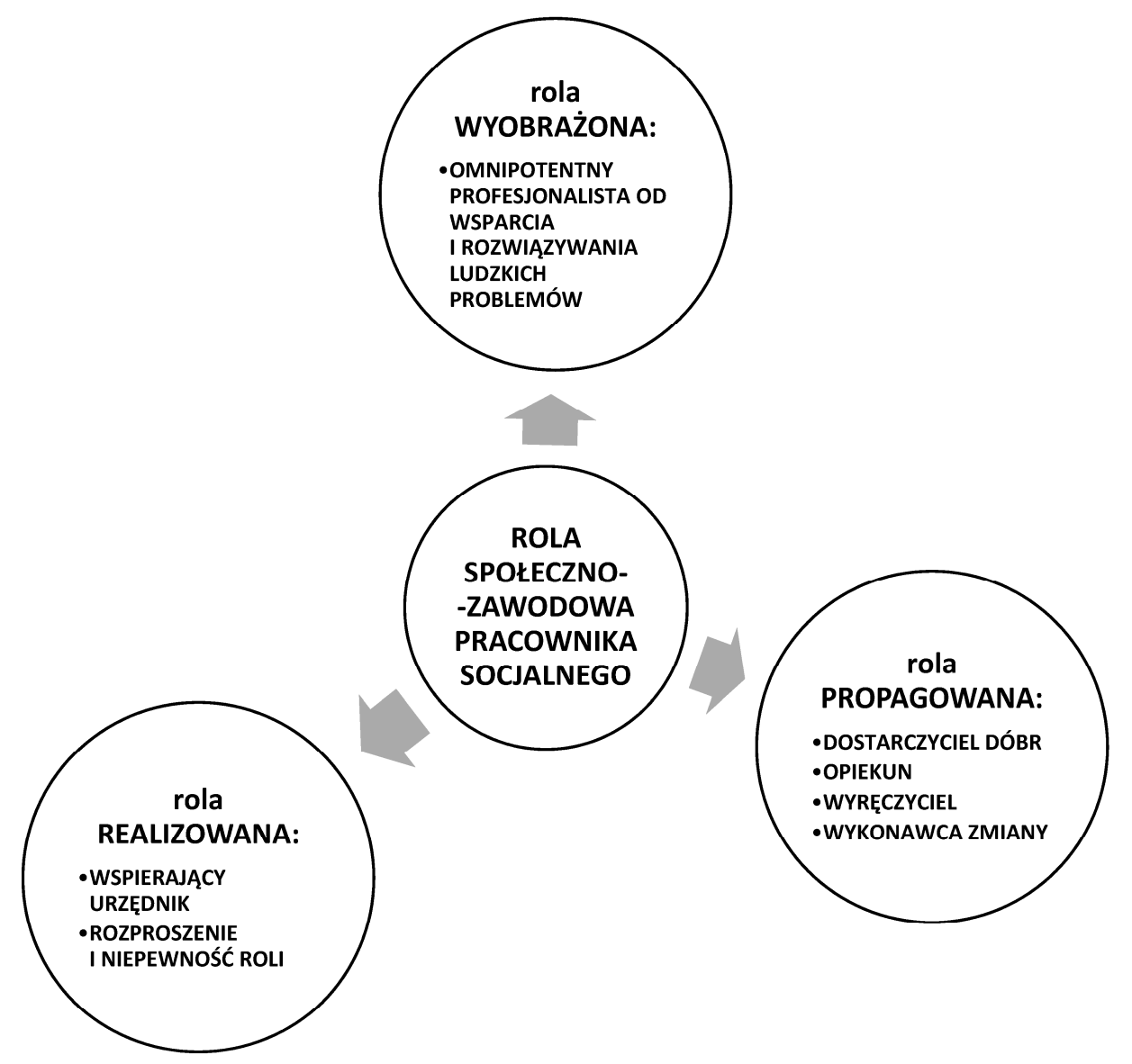

Rysunek 1. Struktura roli społeczno-zawodowej pracowników socjalnych.

Źródto: opracowanie własne na podstawie badań własnych.

Zestawiając powstały model z tradycyjnymi elementami roli społecznej, tj. (1) spójny zespół przepisów, obowiązków i oczekiwań, (2) zbiór przywilejów i praw, (3) repertuar zachowań jednostek w konkretnych sytuacjach, można wyraźnie zauważyć, że pracownicy socjalni skutecznie ominęli własne przywileje i uprawnienia - pomimo że w pytaniu o rolę realizowaną ,uprawnienia” były wymienione. Rysunek 2 obrazuje odniesienie modelu struktury roli społeczno-zawodowej do elementów roli społecznej obecnych w literaturze społecznej (Sztompka, 2003, s. 266-267; Szczepański, 1970; Turner, 1998). 


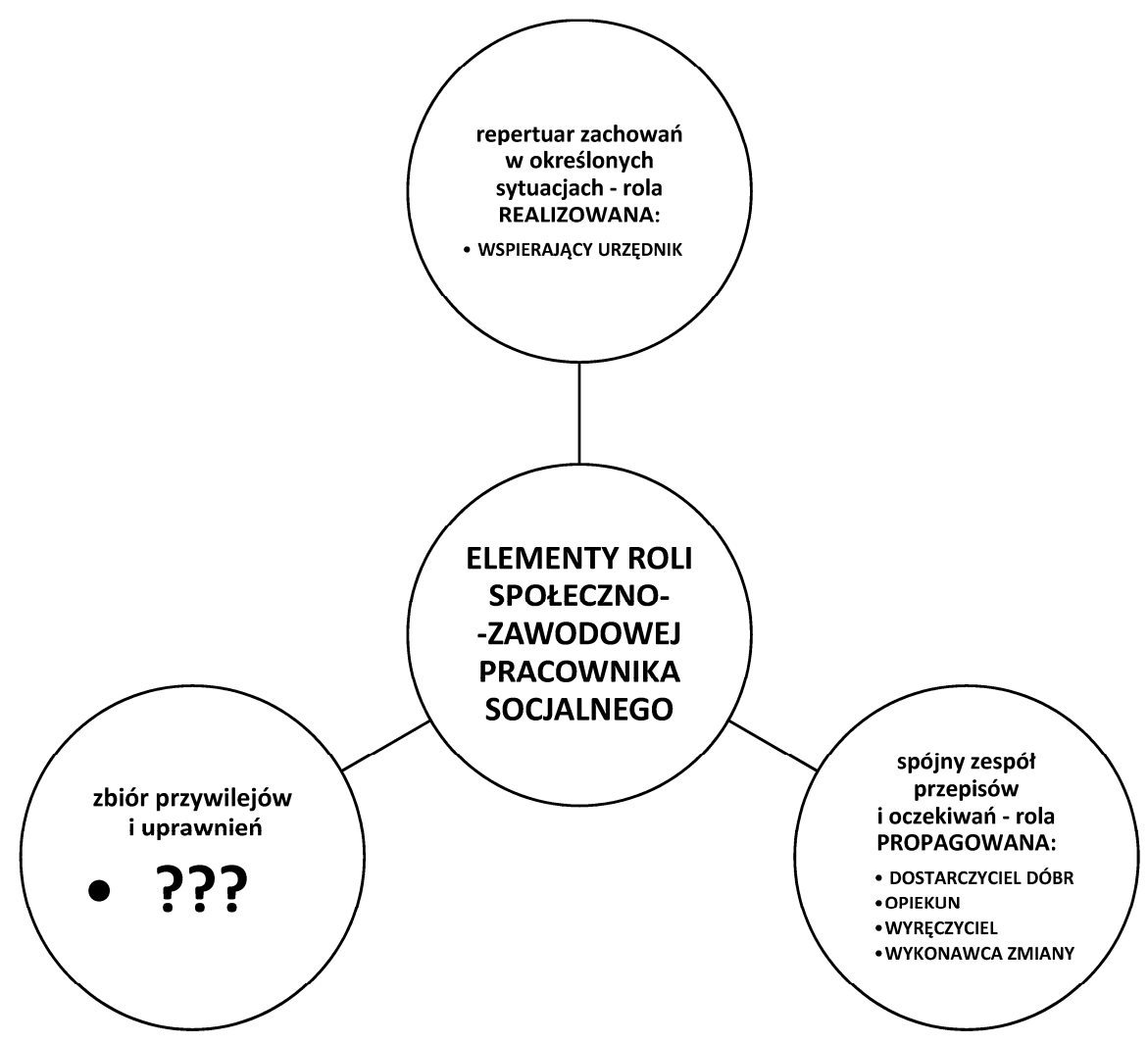

Rysunek 2. Odniesienie modelu struktury roli społeczno-zawodowej do elementów roli społecznej. Źródło: opracowanie własne na podstawie badań własnych.

Na rysunku widać, że oczekiwaniom wynikającym z roli odpowiada rola propagowana, zachowaniom - rola realizowana, a przywilejów i uprawnień wyraźnie brakuje w wypowiedziach pracowników socjalnych, nawet w definicji roli wyobrażonej, która zachęcałaby do nadania sobie określonych praw. Zarówno w roli realizowanej, jak i wyobrażonej pracownicy socjalni nie wspomnieli o uprawnieniach wynikających z zawodu, chociaż obydwa te konstrukty przecież mogłyby zawierać przywileje. Co wpływa na to, że pracownicy socjalni pomijają ważny aspekt własnego sprawstwa i autorytetu? To pewnie rekomendacje do kolejnych badań i zgłębiania owych przyczyn. Niewątpliwie współczesny status społeczno-ekonomiczny zawodu i warunki pracy socjalnej oraz zmiana specyfiki klientów pomocy społecznej mają na to niemały wpływ. 


\section{MODEL ROLI SPOŁECZNO-ZAWODOWEJ PRACOWNIKA SOCJALNEGO Z UWZGLĘDNIENIEM DECYDENTÓW SKUTECZNOŚCI}

Prezentowane badania analizują wątek dotyczący czynników decydujących o skuteczności realizowanej roli pracownika socjalnego. Inspiracją do rozważań na temat decydentów skuteczności roli społecznej jest teoria trzech możliwych błędów w wyjaśnianiu zdarzeń społecznych (Aronson, 2006, s. 155-167). Teoria błędów pokazuje, że kontekst zachowań i kontaktów interpersonalnych, wypełniania ról społecznych i zajmowania pozycji jest dużo szerszy niż wynikający głównie z oczekiwań społecznych i czynników środowiskowych. W opinii pracowników socjalnych wśród czynników decydujących o skuteczności wypełniania roli zawodowej nie sposób nie uznać predyspozycji i cech osobowościowych. Badani zapytani o to, co wpływa na skuteczne i efektywne realizowanie roli pracownika socjalnego, wymieniają m.in.: doświadczenie, możliwość szkoleń, warunki i kulturę pracy oraz własne zaangażowanie, brak oporu, odwagę i wiele innych. W tabeli 2 zestawiono wymienione przez badanych czynniki decydujące według nich o skuteczności roli pracownika socjalnego.

Tabela 2. Decydenty skuteczności roli społeczno-zawodowej pracownika socjalnego

\begin{tabular}{|c|c|}
\hline Czynniki środowiskowe & $\begin{array}{c}\text { Czynniki osobowościowe, } \\
\text { predyspozycje i cechy indywidualne }\end{array}$ \\
\hline $\begin{array}{l}\text { - staż pracy } \\
\text { - doświadczenie zawodowe } \\
\text { - wsparcie przełożonych } \\
\text { - wsparcie kolegów z pracy } \\
\text { - warunki pracy } \\
\text { - kultura organizacyjna instytucji } \\
\text { - możliwość podnoszenia kompetencji } \\
\text { w miejscu pracy } \\
\text { - superwizja } \\
\text { - dostępność specjalistów w instytucji, w której } \\
\text { się jest zatrudnionym } \\
\text { - zewnętrzna sieć współpracy (inne placówki, } \\
\text { przychylne osoby, specjaliści z innych } \\
\text { instytucji) }\end{array}$ & $\begin{array}{l}\text { - zaangażowanie } \\
\text { - umiejętność dostosowania się do trudnych śro- } \\
\text { dowisk i warunków pracy } \\
\text { - otwartość na niestandardowe rozwiązania } \\
\text { - komunikatywność } \\
\text { - inteligencja emocjonalna } \\
\text { - samodyscyplina } \\
\text { - odwaga } \\
\text { - otwartość } \\
\text { - odporność na wstręt } \\
\text { - empatia } \\
\text { - intuicja } \\
\text { - determinacja w dążeniu do celu } \\
\text { - wiara w siebie } \\
\text { - upór } \\
\text { - brak oceny innych } \\
\text { - chęć pomocy } \\
\text { - chęć dominacji }\end{array}$ \\
\hline
\end{tabular}

Źródto: opracowanie własne na podstawie badań własnych. 
Decydenty skuteczności roli pracownika socjalnego uzupełniają model o ważny ludzki czynnik i - co ciekawe - nie tylko wśród elementów wyłącznie indywidualnych. Jak wskazują pracownicy socjalni, równie ważne jest, aby cechy otwartości, odwagi, gotowości i zaangażowania występowały także u przełożonych i innych, z którymi współpracują. Jak sami mówią: „Ja mogę kombinować jak umiem i starać się, ale bez spoko przełożonych nic się nie zrobi”. Rysunek 3 przedstawia model roli społeczno-zawodowej pracownika socjalnego z uwzględnieniem decydentów skuteczności.

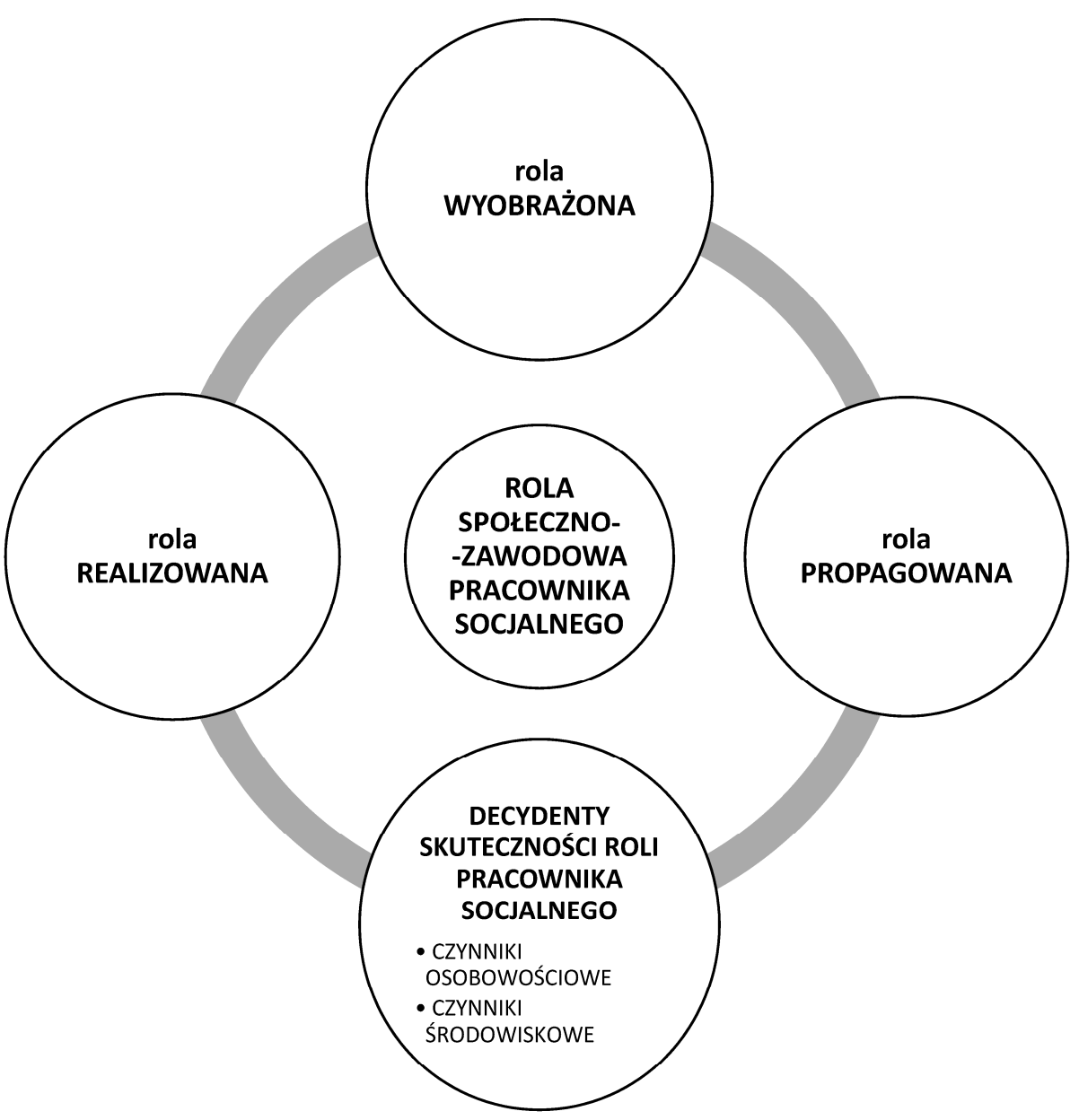

Rysunek 3. Model roli społeczno-zawodowej pracownika socjalnego z uwzględnieniem decydentów skuteczności.

Źródto: opracowanie własne na podstawie badań własnych. 
Zaproponowany model roli społeczno-zawodowej pracownika socjalnego przedstawia oddziaływanie na siebie wzajemnie wszystkich jego konstruktów. Bez pewniej determinacji i predyspozycji wiele osób nie mogłoby być pracownikami socjalnymi. Owe predyspozycje można z kolei odnaleźć w cechach, które pracownicy socjalni nazywają decydującymi przy osiąganiu rezultatów swojej pracy. I w ten sposób koło się zatacza, tworząc swoisty cykl. Potrzebne są pewne cechy, żeby w ogóle myśleć o zawodzie pracownika socjalnego (rola wyobrażona) i być gotowym na tak duże społeczne oczekiwania (rola propagowana). To z kolei, w połączeniu z czynnikami środowiskowymi i indywidualnymi (decydenty skuteczności), pozwala z determinacją pracować $\mathrm{w}$ jednym $\mathrm{z}$ najstarszych zawodów - w pomocy społecznej (rola realizowana). Pracownicy socjalni są zgodni co do tego, że bez tych cech nie da się wykonywać zawodu na stałe.

\section{WNIOSKI - REKOMENDACJE}

Podsumowując rozważania na temat roli społeczno-zawodowej pracownika socjalnego, warto zwrócić uwagę na wyzwania i potrzeby, jakie się pojawiają (Kotlarska-Michalska, Sikora, 2015). Po pierwsze - nasuwa się potrzeba rozszerzenia badań dotyczących roli pracowników socjalnych, chociażby o kolejne grupy badawcze, np. beneficjentów pomocy społecznej, zarządzających OPS-ami czy członków społeczności lokalnych. Ta ostatnia grupa może szczególnie poszerzyć wnioski w kontekście roli społeczno-lokalnej, jaką pełni pracownik socjalny. Po drugie - analiza wywiadów z pracownikami socjalnymi pozwala sformułować kilka istotnych dla praktyki pracy socjalnej rekomendacji. Pracownicy socjalni, by skutecznie realizować rolę zawodową, potrzebują dobrze wypracowanej, zorganizowanej i zaufanej sieci współpracy oraz nowych przepisów, które to umożliwią, najlepiej obligatoryjnie. Zidentyfikowane czynniki środowiskowe wśród decydentów skuteczności wskazują na potrzebę podziału kompetencji i jasności co do struktury pracy, przychylności przełożonych i możliwości realizowania twórczych odważnych działań. A ponadto wzmocnienia uprawnień i kompetencji pracowników socjalnych po to, by sami mogli dostrzec swoją sprawczość i zacząć traktować siebie jak specjalistów. Prezentowane badania wykazały, że ważnymi czynnikami w realizowaniu i tworzeniu roli zawodowej pracowników socjalnych są czynniki osobowościowe. Nasuwa to wniosek o potrzebie wsparcia dla pracowników socjalnych we wzmacnianiu własnych zasobów i predyspozycji 
do pełnienia roli zawodowej. Rozwiązaniem skutecznym i systemowym w tym obszarze mogłaby być powszechna, dostępna superwizja.

\section{BIBLIOGRAFIA}

Aronson E. (2006), Człowiek istota społeczna, Warszawa: Wydawnictwo Naukowe PWN.

Babbie E. (2008), Podstawy badań społecznych, Warszawa: Wydawnictwo Naukowe PWN.

Beckett Ch. (2010), Podstawy teorii dla praktyków pracy socjalnej, Warszawa: Wydawnictwo Akademii Pedagogiki Specjalnej.

Buber M. (1992), Ja i Ty. Wybór pism filozoficznych, Warszawa: Instytut Wydawniczy PAX.

Creswell J.W. (2013), Projektowanie badań naukowych. Metody jakościowe, ilościowe i mieszane, Kraków: Wydawnictwo Uniwersytetu Jagiellońskiego.

Czechowska-Bieluga M. (2013), Poczucie zadowolenia z życia pracowników socjalnych w socjopedagogicznej perspektywie uwarunkowań petnionej roli zawodowej, Lublin: Wydawnictwo UMCS.

Giddens A. (2006), Socjologia, Warszawa: Wydawnictwo Naukowe PWN.

Juszczyk S. (2005), Badania ilościowe w naukach społecznych. Szkice metodologiczne, Katowice: Śląska Wyższa Szkoła Zarządzania im. gen. Jerzego Ziętka.

Kantowicz E., Ciczkowska-Giedziun M., Zmysłowska M. (2018), Social work in Poland in times of transition, Olsztyn: Wydawnictwo Uniwersytetu Warmińsko-Mazurskiego.

Kotlarska-Michalska A., Sikora P. (2015), Praca socjalna. Przeszłość - teraźniejszość - przyszłość, Opole: Wydawnictwo Uniwersytetu Opolskiego.

Levin J. (1985), Functionalism and the argument from conceivability, Canadian Journal of Philosophy, nr 11, s. 85-104.

Merton R.K. (2002), Teoria socjologiczna i struktura spoteczna, Warszawa: Wydawnictwo Naukowe PWN.

Nieciuński S. (1979), Aksjologiczne i psychospołeczne aspekty społecznej roli nauczyciela-wychowawcy, Nowa Szkoła, nr 11, s. 32.

Nowak, S. (2007). Metodologia badań społecznych, Warszawa: Wydawnictwo Naukowe PWN.

Parsons T., Smelser N.J. (1975), Funkcjonalne zróżnicowanie społeczeństwa, [w:] W. Derczyński, A. Jasińska-Kania, J. Szacki (red.), Elementy teorii socjologicznych, Warszawa: Wydawnictwo Naukowe PWN, s. 47-70.

Sołoma, L. (2002), Metody i techniki badań socjologicznych. Wybrane zagadnienia, Olsztyn: Wydawnictwo Uniwersytetu Warmińsko-Mazurskiego.

Szczepański J. (1970), Elementarne pojęcia socjologii, Warszawa: Wydawnictwo Naukowe PWN.

Sztompka P. (2003), Socjologia, Warszawa: Wydawnictwo Naukowe PWN.

Turner J.H. (1998), Socjologia. Koncepcje i ich zastosowanie, Poznań: Zysk i S-ka.

Turnowiecki J. (2001), Socjologia. Małe struktury społeczne, Lublin: Towarzystwo Naukowe KUL. 


\section{MODEL ROLI SPOŁECZNO-ZAWODOWEJ PRACOWNIKA SOCJALNEGO W KONTEKŚCIE TEORII RÓL. DYSKUSJA Z BADAŃ}

\section{Streszczenie}

Celem artykułu jest analiza roli społeczno-zawodowej pracownika socjalnego przy uwzględnieniu teorii ról społecznych i zasadniczych elementów roli. Rezultatem analizy jest - zaprezentowany w artykule - model roli społeczno-zawodowej pracownika socjalnego. Artykuł stanowi refleksję naukową w kontekście zadań, oczekiwań i uprawnień, jakie stoją przed pracownikami socjalnymi. Autorka analizuje aktualną literaturę z zakresu socjologii i psychologii społecznej oraz prezentuje dyskusje z jakościowych badań terenowych, przeprowadzonych w okresie od listopada 2020 do stycznia 2021. Badania odbywały się techniką pogłębionych wywiadów indywidualnych, w których wzięli udział pracownicy socjalni z Lublina, Radomia i Puław. W ramach podjętych badań autorka analizuje sposób percepcji roli społeczno-zawodowej przez pracowników socjalnych. Artykuł jest głosem w dyskusji na temat zawodowych ról pracowników pomocy społecznej i zadań, jakie przed nimi stoją. Analiza wyników badań daje sposobność do wskazania potrzeb pracowników socjalnych oraz wyzwań stojących przed systemem, w którym funkcjonuje analizowany zawód.

Słowa kluczowe: praca socjalna; rola społeczna; rola zawodowa.

\section{MODEL OF THE SOCIAL AND PROFESSIONAL ROLE OF A SOCIAL WORKER IN THE CONTEXT OF ROLE THEORY. RESEARCH DISCUSSION}

\section{Summary}

The goal of the article is to analyze the socio-professional role of a social worker, taking the theory of social roles and the main elements of the role. The result of the analysis is the model of the social and professional role of a social worker presented in the article. The article is a scientific reflection in the context of tasks, expectations and rights that are faced by social workers. The author analyzes the current literature in the field of sociology and social psychology and presents discussions on qualitative field research conducted in the period from November 2020 to January 2021. The research was conducted using the technique of in-depth individual interviews, in which social workers from Lublin, Radom and Puławy participated. As part of the research undertaken, the author analyzes the perception of the social and professional role by social workers. The article is a voice in the discussion on the professional roles of social workers and the tasks they face. The analysis of the research results gives the opportunity to indicate the needs of social workers and the challenges faced by the system in which the profession operates.

Keywords: social work; social role; professional role. 